Article

\title{
Translating the Greeks: The Divine Faithlessness of Hölderlin
}

Soumick De

\begin{abstract}
The paper is an attempt to examine the place of Hölderlin in relation to the philosophical, historical, and aesthetic discourse of his time. Examining the concept of tragedy in Hölderlin, we would try to understand how the problem of separation in metaphysics, opened by Kant, expressed itself in history. Moreover, through an exploration of such ideas like that of the proper/non-proper and the aorgic (ancients)/organic (Hesperian/modern) in Hölderlin, the paper would try to argue that instead of a dialectical resolution to the problem of history and art, what Hölderlin sought was the intensification of an arche-separation. In other words, we would try to understand the meaning of an original difference which Hölderlin proposes as the condition for a concept of translation. Yet such translation would speak only of the impossibility of imitating or returning to the Greeks, of constantly being faithless to the Greek reality such that this faithlessness becomes the very basis of the singularity of the modern condition. How to be faithful to this faithlessness so that the Greeks continue to speak without saying anything? The paper would be an attempt to examine this paradox of translation in Hölderlin.
\end{abstract}

Keywords: Tragedy, aesthetics, translation, arche-separation

\section{The General Problem as a Problem of History: The Quest for Epochal Totalization?}

The shadow cast by the Greeks onto the horizon of German thinking in the aftermath of the French Revolution is undeniable. It was an epoch of German thinking which is also to say a thinking Germany which wanted to inscribe its name, and thereby, mark the epoch as German. ${ }^{1}$ But instead of a

${ }^{1}$ This can perhaps be argued as a problem of historical double binding where the desire of German idealism was not only to produce an epoch characterised by its spirit of thinking but self-consciously inscribe that very spirit on to history in order to find its place and recognise itself as German-a double binding which Phillipe Lacoue-Labarthe has pointed in his

(c) 2019 Soumick De

https://www.kritike.org/journal/issue 24/de june2019.pdf

ISSN 1908-7330 
new epoch born singularly under the sign of modernity, it became a moment in the history of German thought which ironically was caught in a gigantic historical double bind. Johann Joachim Winckelmann's remark captures this exhaustible desire of a nation which would miss its own birth when he wrote "the only way we can become great and if this is possible, inimitable, is by imitating the Ancients." 2 The shadow cast by the Greeks was fast transforming into the twilight of enlightenment when a dawn was conceived in the form of a theoretical solution. What was sought was nothing less than a dialectical resolution to the crisis whose metaphysical origins lead back to Kant. In other words, working from within the mimetic logic of imitating the Greeks, the "thinking Germany of the $1790 \mathrm{~s}^{\prime \prime} 3$ believed to have found a way of overcoming the crisis such that the Moderns would become master of the masters.

Of course, the central philosophical problem was to find some kind of commensurability to the incommensurable gap opened up by Kantian thinking in the very heart of metaphysics. The separation which came in a series of metaphysical oppositions such as subjective/objective, speculative/intuitive, sensible/ideal, necessary/free among others found their way into domains of history and art, giving rise to such binaries like Ancients/Moderns, Nature/Culture, plastic arts/poetic arts, and epic/lyric. It is Schiller who seems to have broken this "indefinitely binary rhythm of identificatory cyclothymia." 4 When Schiller announced that "nature in us has disappeared from humanity," ${ }^{5}$ he not only Rousseau-esquely echoed the 'sentimental' desperation of the moderns, the beings of culture-to re-turn to the 'naïve' state where being nature, the simple and feeling poet had only to imitate actuality. Schiller wanted not simply to create a schema for this opposition but find a reconciliation, even a speculative one. Thus, he would argue that if reflective understanding stood contrary to naïve perception, then "the sentimental mood is the result of the effort, even under the conditions of

essay “Hölderlin and the Greeks." See Phillipe Lacoue-Labarthe, "Hölderlin and the Greeks," in Typography (Stanford, CA: Stanford University Press, 1998).

2 For a precise understanding of Winckelmann's relation to the Greeks which, in a sense summed up the epoch in German thinking, see Johann Joachim Winckelmann, "Thoughts on the Imitation of Greek Works in Painting and the Art of Sculpture," in Johann Joachim Winckelmann on Art, Architecture, and Archaeology, trans. by David Carter (Rochester and New York: Camden House, 2013), 31-55.

${ }^{3}$ The crisis of modernity in its relationship to the Greeks was experienced in the works of a number of German thinkers of the time like Johann Gottfried Herder, Karl Philipp Moritz, and later by Schiller and the great wave of German romanticism. See Lacoue-Labarthe, "Hölderlin and the Greeks," 237.

${ }^{4}$ Lacoue-Labarthe, "Hölderlin and the Greeks," 237.

${ }^{5}$ Friedrich von Schiller, "Naïve and Sentimental Poetry," in Naïve and Sentimental Poetry and On the Sublime: Two Essays, trans. by Julius A. Elias (New York: Frederick Ungar Publishing Co., 1966), 103.

(C) 2019 Soumick De

https://www.kritike.org/journal/issue 24/de june2019.pdf

ISSN 1908-7330 


\section{THE DIVINE FAITHLESSNESS OF HÖLDERLIN}

reflection to restore naïve feeling according to its content. This would occur through the fulfilled ideal in which art again encounters nature." 6 If sentimental is the contrary of naïve (Ancient), then it must carry within itself the condition for its own transgression, 'a step outside itself,' cancelling and preserving its opposite from which it arose. In other words, the sentimental sublates the opposition between the Naïve and Sentimental, the Ancients and the Modern.

The post Kantian world 7 haunted by the crisis of exile- of Being from appearance, of subject from object, of universal from particular, of man from nature-would not only turn to the tragic propelled by a desire for re-turn. German idealism would theoretically seek to fulfil the promise of the Ancients - what was only an imitation of the actualisation of nature-by orienting its passage through its opposite. The dissociation, the alienation of civilization was only to re-unite with nature but, at an elevated level, an ideal level of humanity. Hölderlin would not remain far from this trajectory of thought (i.e., dialectical thinking) not only because of his relation to German Idealist thinking of the time but also because of his profound engagement with Greek tragedy. But in what way does Hölderlin, the modern poet contribute to this desire for the tragic which informed speculative thinking? In what manner was he positioned in the midst of this tragic turn of German idealism?

In a letter to Schiller from 4 September 1795, Hölderlin writes

I try to prove that what we should insistently demand of any system, the union of subject with object in an absolute I (or whatever you want to call it) is undoubtedly possible in an aesthetic manner, in intellectual intuition, but is possible in a theoretical manner only by way of infinite approximation. ${ }^{8}$

This spirit of infinitizing, or absolutizing, sought through dialectic, is a tendency which we cannot ignore in Hölderlin. It can be argued, though probably not here, following Philippe Lacoue-Labarthe, that this dialectical

\footnotetext{
${ }^{6}$ Ibid., 154-155.

7 The crisis of the post Kantian world was a crisis of transcendence which had many effects within and outside philosophy. In politics for example this crisis would translate into the emergence of the modern state which is separated from any theological justification of a divine foundation. We are however concerned with the metaphysical consequences of this crisis particularly as it transformed speculative thinking in Germany during the late $18^{\text {th }}$ and early $19^{\text {th }}$ century.

8 Friedrich Hölderlin, Werke und Briefe, ed. by Friedrich Beissner (Frankfurt: Insel Verlag, 1969), 846 as quoted in Lacoue-Labarthe, "Holderlin and the Greeks," in Typograhy, 241.
} 
triumphalism is closely related to a mimetological tendency which is the very 'model' for modern western historical consciousness. Further that, this imitating heart of historicization is founded upon a cathartic and finally sacrificial logic which needs to be critically analysed as the basis of western culture. But all that gets interrupted, at least in Hölderlin, by the time his efforts at writing a 'modern tragedy' fails and he starts engaging himself with the problem of theatre and his translations of Sophocles. From his writings of this period, roughly starting from 1800-1801, particularly the intensely elliptical notes on his translations and some of the letters addressed to his friend Bohelendorff and to his editor, we come to see an historical and aesthetic imagination which is truly original, and whose place within German Speculative Idealism is inimitably singular. It is during this period that Hölderlin introduces the theme that Greece, at least in itself, does not exist ${ }^{9}$ and that it is impossible to imitate it in any manner. This tension interrupting the dialectical resolution of the question of history (Ancients/Moderns) is expressed in categories that Hölderlin creates-proper and non-proper, the native or national and foreign, the aorgic and the organic. That these categories are an echo of the already prevalent dichotomies existing at the time like that of the Ancients/Modern binary or even the more complex Schillerian contradiction of the naïve and the sentimental should not come as a surprise. But what is perhaps singular to Hölderlinean thinking is the imperative which he claims to be the governing principle of any culture or historical epoch so that it can assume what is proper to itself, where it ought to belong and with which it tends to identify. Hölderlin recognises a drive, a pull within history which paradoxically urges that which is proper to first pass through that which is not proper to itself, to exit its own territory such that it can enter itself, enter for the first time, and assume its place in history only on the condition that it has exited. In other words, the place of exit is inscribed in the very heart of a culture's entry into its own proper place. To pass through this other, this foreign land, not to come back and possess what is one's own but to re-turn to a dis-possession becoming an alien in one's own homeland, a nomad who goes nowhere, but brings his nomadism to the very centre of the polis. This could only be possible if, instead of differences, temporal (Ancients) or spatial (Greece), being subsumed under an identity, identities came to be conditioned by an original difference. Instead of merely

9 At the heart of this enigmatic conclusion was Hölderlin's conviction which was unambiguously philosophical that there remains an incommensurable gap or a caesura between what we know of Greece or even how it manifested itself and what it really was. This is a philosophical problem per excellence directed at representation which is to say the relation between being and appearance. While for Hölderlin there is no just idea about ancient Greece, modern west including Germany which the poet designates with a general term Hesperia also does not exist or better exists only as a possibility. 


\section{THE DIVINE FAITHLESSNESS OF HÖLDERLIN}

distinguishing proper from non-proper, native from foreign, such distinction somehow manages to not only separate these categories, (geographical, historical, aesthetic) but separate itself. In other words, difference differentiates itself in order to fold back on to the other, passing through it, such that in order to become what one is, one must first traverse that which one is not. As we would try to show in the final section of this paper, this same paradox finds its most prominent expression in the language of Hölderlin, such that in order to become a work, it must continuously pass through the absence of work, thereby breaking the epic unity of an artist and his work. We shall come to this problem of language in a while. But let us start with an examination of the problem of history in Hölderlin.

For Hölderlin, to say that the Greeks did not exist did not mean that as a culture the Greeks did not produce any meaning innate to itself. On the contrary, what was native to the Greeks was, according to the poet, a certain oriental mystical intensity, a play of the forces, an elemental drive. The element proper to the Greeks was the 'fire of heaven,' a 'sacred pathos' of being a victim of the divine, a death drive, if you may, which translates in their desire for transgressing the limits of finitude. This is what he imagines as the aorgic nature of the Greeks as against the occidental organic nature of the moderns. But even the moderns for Hölderlin are not a pre-supposed category, a historically given reality, but a fictive reality, a sign of the future, which he calls the Hesperian. In other words, contemporary reality can only come as a sign which is the vessel for another desire, another drive which is that of a yet to come. However, this future is already present in language, as a sign which manifests the perilous reality of such a possibility. We shall return to this point in a while.

But as for the aorgic Greeks, it is this drive to overcome the boundaries of finite existence which also makes them speculative par excellence, because it is quite literally a metaphysical desire which fuels their imagination and constantly urges them to transgress the limits (hubris) of the finite world to unite with the 'one-all'10. But it is this desire which also pushes them towards that which is foreign to them: the world of art or more precisely the reality of tragic art. Tragedy, as Hölderlin imagines it as the monstrous coupling of God and Man, is the very threshold, the edge of the void standing on which the Greeks could look into the limitless abyss, transgressing mortal limits and yet express such transgression in a purified form. Hence, tragedy

${ }^{10}$ We find the idea of one-all in many of Hölderlin's texts. In the true spirit of Enlightenment, a totalizing impulse dominates Hölderlin's thinking but in a fashion, which brings him infinitely close yet incommensurably beyond the reach of his contemporaries. For a brilliant exposition of this problem in Hölderlin see Jean-François Courtine, "Of tragic metaphor," in Philosophy and Tragedy, ed. by Miguel de Beistegui and Simon Sparks (London and New York: Routledge, 2000), 57-75.

(C) 2019 Soumick De

https://www.kritike.org/journal/issue 24/de june2019.pdf

ISSN 1908-7330

(cc) BY-NC-ND 
was also the sobriety of form, the measure of capturing that which was not possible to capture, but more importantly, something which was foreign to the Greeks to which they had to apply themselves that resulted in forgetting the forgetful gods. Under the sign of tragedy, the Greeks no longer desired the infinite becoming one-whole, but became faithful to their own infidelity, a divine faithlessness which in turn made them so desirable. The sobriety of art, which was foreign to the Greeks, through which they nevertheless had to pass through in order to appropriate that which was proper to them, made the Greeks into an 'empire of art,' but at the same time, it transformed the metaphysical desire which was native to the Greeks into something artistic, which itself became desirable. Thus Hölderlin in his letter to Bohlendorff would write "... the Greeks are less master of the sacred pathos, because to them it was inborn, whereas they excel in their talent for presentation, beginning with Homer, because this exceptional man was sufficiently sensitive to conquer the Western Junonian sobriety for his Apollonian empire and thus to veritably appropriate what is foreign." 11 There is nothing natural about this naïve art of the Greeks, while at the same time, to be desirable need not mean that the Greeks are an object of desire whose fulfilment lies in the speculative consummation of Greek aesthetics.

We would like to argue that when Hölderlin remarks that the Greeks do not exist what is meant is that they exist as nothing but desire, as nothing but what we want to make of them. However, what is desirable about the Greeks is not their substantial reality, which we do not possess, but their very desire for transgression, their desire of becoming one-whole. What makes the Greeks desirable is desire itself. We desire the Greeks in their desire for the abyss. And tragedy is the site where it plays itself out. This is also the reason why we are not capable of tragedy, because our tragedy is precisely the absence of tragedy. That is to say that modern tragedy is not possible because all we want is tragedy, which is not given to us because we do not have destiny. The theme of this loss of destiny (dysmoron) recurs in many of Hölderlin's most famous works. In his poem "Bread and Wine" we have the following line "Delphi's asleep, and where now is great fate to be heard?"

${ }^{12}$ Neither do we have the great oracles of the Greeks nor do we have a fiery volcano to jump into and become one with the one-whole, as did

${ }^{11}$ Friedrich Hölderlin, "Selected Letters: No. 236, To Casimir Ulrich Böhlendorff," in Friedrich Hölderlin: Essays and Letters on Theory, trans. and ed. by Thomas Pfau (Albany, NY: SUNY Press), 149-150.

${ }^{12}$ Friedrich Hölderlin, "Brod und Wein / Bread and Wine," trans. by M. Hamburger, in Hyperion and Selected Poems, ed. by Eric Santner (New York: Continuum, 1990), 183.

(C) 2019 Soumick De

https://www.kritike.org/journal/issue 24/de june2019.pdf

ISSN 1908-7330

(cc) BY-NC-ND 


\section{THE DIVINE FAITHLESSNESS OF HÖLDERLIN}

Empedocles, the philosopher-hero of Hölderlin's never completed play "Death of Empedocles." ${ }^{13}$ The negation of the tragic is the modern reality.

Hölderlin writes "For this is the tragic to us: that packed up in any container, we very quietly move away from the realm of the living, [and] not that-consumed in flames-we expiate the flames which we could not tame." 14 This unquenchable flame, this insatiable desire for that which is outside, which can only come as a transgression, is not our reality. What we have is the silent search for an address, a nomadic pursuit in desire, to somewhere which is anywhere; an anonymity which must also be clamorous because it strikes out at something, resonating in the other. It is a silence and an anonymity found in madness (as we shall try to show in the last section) which strikes out through language at something; perhaps a new body which can be re-born, immanent to the world, fragile but more original than that which was born before. Hölderlin's note on Antigone perhaps leads one to think along these lines. He writes

For us, existing under the more real Zeus who not only stays between this earth and the ferocious world of the dead, but who also forces the eternally anti-human course of nature to another world more decidedly down onto earth, and since this greatly changes the essential and patriotic representations, and since our poetry must be patriotic so that its themes are selected according to our world-view and their representations patriotic, for us, then, the Greek representations change insofar as it is their chief tendency to comprehend themselves, which was their weakness; on the other hand it is the main tendency in the mode of representation of our time to designate something, to possess a skill, since the lack of destiny, the dysmoron, is our deficiency. ${ }^{15}$

If Greek art was a desire to express who the Greeks were and thereby be lost to themselves, our artistic imperative is to effectuate something, force something out of art or more precisely perhaps, out of language, a vessel, an address conditioned by our weakness which is the absence of destiny. The categorical turning away of the gods coincides with the divine faithlessness of man such that, man is forced by this arche-separation to turn his view from

\footnotetext{
${ }^{13}$ See Friedrich Hölderlin, The Death of Empedocles: A Mourning-Play, trans. by David Farrell Krell (Albany, NY: SUNY Press, 2008).

${ }^{14}$ Hölderlin, "Selected Letters: No. 236, To Casimir Ulrich Böhlendorff," 150.

${ }^{15}$ Friedrich Hölderlin, "Remarks on 'Antigone'," in Essays and Letters on Theory, 113114 . 
heaven towards the earth and on to himself. A turning of the self in its own place such that he can transform himself into something which would give him a singular point of view, no longer determined by the desire for heaven but a longing to strike something, a "formative drive" oriented towards a goal. In a short fragment titled "The Perspective from which We Have to Look at Antiquity" 16 Hölderlin condemns the positive given manner in which we look at the Ancients because it has been appropriated, learnt as something pre-formed. Against or in spite of such appropriation, Hölderlin imagines the current circumstances as fertile with the possibility of orienting ourselves to something more worthwhile than a puerile imitation of antiquity. Hence, he warns that the only mistake one can make now is to let "his formative drive" deviate from the goal which is its 'address' ${ }^{\prime 17}$ in absence of all destiny. He remarks,

for this is man's only mistake, that his formative drive goes astray, takes an unworthy altogether mistaken direction, or at least misses its proper place, or if it has found it comes to a halt in the middle of the way with the means which are supposed to lead him to his goal. ${ }^{18}$

Clearly, for Hölderlin, this orientation of the desire is purely aesthetic on the one hand, while on the other, the proper place sought is always conditioned by that which is outside the place, which is always an elsewhere. The proper place is equivalent to something like the object of desire which is always out of reach. Tragic desire is a desire which does not ask for an object whose knowledge is available, and which can therefore be fulfilled. It is a desire for something which is completely alien, monstrous and without any available knowledge. A desire which is fuelled by a monstrous lack of its object is the tragic desire which articulates itself in language. Therefore, tragic desire becomes the semantic demand of language which is never fulfilled because it can never refer to anything given. What we witness in Hölderlin is the primordial struggle of a formative desire which seeks a 'unique rhythm' through language. In other words, it seeks to perform, in language, the task to address, not simply to communicate, ${ }^{19}$ because one has nothing to

\footnotetext{
${ }^{16}$ Friedrich Hölderlin, "The Perspective from which We Have to Look at Antiquity," in Essays and Letters on Theory, 39-40.

${ }^{17}$ In the Thomas Pfau translation, it is translated as "designation".

${ }^{18}$ Hölderlin, "The Perspective from which We Have to Look at Antiquity," 39-40.

${ }^{19}$ For a brilliant discussion of the difference between the communication of language and its communicability see Walter Benjamin, "On Language as Such and on the Language of Man," trans. by Edmund Jephcott in Selected Writings: Volume 1, 1913-1926, ed. by Marcus Bullock and Michael W. Jennings (Cambridge, MA: The Belknap Press of Harvard University Press, 1996).
}

(c) 2019 Soumick De

https://www.kritike.org/journal/issue 24/de june2019.pdf

ISSN 1908-7330 
communicate. Language ceases to communicate as it fails to demonstrate anything and becomes the expression of what Jacques Lacan would later call a "monstration". Because language is, here, caught in this desire for a "monstrous" and completely alien outside; it has no destiny to fulfil, and hence, no destination to reach. And without destination, how can there be communication? So tragic language begins to (de)monstrate itself. And yet something has to be addressed. One has to strike out to something which one encounters even if it is a monstrous nothingness whose knowledge we do not possess but which, nonetheless, stands as threshold, a boundary which helps us to form certain relations with ourselves and others. Its proper place is language, because it is in language that this threshold (dis)articulates itself in its clarity and polysemy. Hence, we need to study the role not only of tragedy but of language itself in the works of Hölderlin a bit more closely. The next section of the paper would be devoted to this purpose of studying the problem of tragedy and language while the last section would take up the question of language and madness in order to examine the problem of history as briefly outlined above.

\section{The General Problem as a Problem of Language: Tragedy}

In one of his Hamburg essays concerned with the study of the major genres or modes of poetry titled "On the Difference of Poetic Modes," we find one of the earliest definitions of the tragic poem in Hölderlin. In it, Hölderlin differentiates between the three major modes of poetry: lyric, epic and tragic, further subdividing them into sub-genres according to their basic tone. Hence, each genre or mode or appearance (or "art-character" or "tendency") would signify the basic or fundamental tone which is its spirit or dwelling. Thus, the fundamental tone (stress) would be divided according to the tonalities it would appear in its art-character which were: the naïve, the idealistic and the heroic. In respect to such division, the definition of the tragic poem offered in the very beginning of the text is as follows: "The tragic, in appearance heroic poem, is idealistic in its signification. It is the metaphor of an intellectual intuition." 20 Following Jean-Francois Courtine's lead, we need to understand metaphor here almost literally-metaphora-as transport or translation or transposition, even impropriety or forcing of something un-said through an improper medium. ${ }^{21}$ But what is being transferred here is not merely a name in the Aristotelian sense of lexis but a tonality or a tone, an order proper to

\footnotetext{
${ }^{20}$ Friedrich Hölderlin, “On the Difference of Poetic Modes," in Essays and Letters on Theory, 83.

${ }^{21}$ For an excellent exposition of the significance of metaphor in Hölderlin's thinking of theatre which in a sense challenges the tragic model of German idealism see the Courtine, "Of tragic metaphor."

(C) 2019 Soumick De

https://www.kritike.org/journal/issue 24/de june2019.pdf

ISSN 1908-7330
}

$(\mathrm{Cc}) \mathbf{B Y - N C - N D}$ 
itself displacing it into another order which would always be alien to it, improper or foreign to it. It is in this sense of the transport that intellectual intuition becomes a metaphor for the tragic poem. But what is the meaning of intellectual intuition in Hölderlin? From a text dating back to 1795 titled Judgement and Being we get a clear idea (almost clear) of the meaning of intellectual intuition in Hölderlin. He writes:

Being-expresses the connection between subject and object. Where subject and object are united altogether and not only in part, that is, united in such a manner that no partition can be performed without violating the essence of what is to be separated, there and nowhere else can being pure and simple be spoken of, as is the case with intellectual intuition. ${ }^{22}$

If the tragic poem stands as a metaphor for intellectual intuition, then it offers a passage or a "sensible egress" for the originary unity to be expressed, presented or staged. As Courtine remarks, "The tragic poem is what 'gives rise' to intellectual intuition, it allows it to take place insofar as it offers it the theatre of a possible 'propiation,' even if, paradoxically, this unity-the unity of the 'primordially united'-only ever presents itself improperly by obscuring or annulling the very 'sign' properly destined to manifest it." 23 We hear in this remark of Courtine an echo of Hölderlin's understanding of the significance of tragedy, where original matter appears only in the weakness or the impropriety of the sign, (remember the formula $S=0)^{24}$ thus rendering it insignificant. Thus, the Hölderlinean idea of the tragic effect is one-whole. But here, one-whole has to be seen for what it is, which is not the pathos of sacrifice to the whole, but the sensibility of the whole in the parts such that the whole is maintained in the parts but only as separation or individuation. "Intellectual intuition maintains the whole in its parts by restoring the parts to its arche-unity which can only be actualised by recognizing the separability

22 Friedrich Hölderlin, "Judgment and Being," in Essays and Letters on Theory, 37-38.

${ }^{23}$ Courtine, "Of tragic metaphor," 60.

24 "The significance of tragedies can be understood most easily by way of paradox. Since all potential is divided justly and equally, all original matter appears not in original strength but, in fact, in its weakness, so that quite properly the light of life and the appearance attach to the weakness of every whole. Now in the tragic, the sign in itself is insignificant, without effect, yet original matter is straight forward. Properly speaking, original matter can only appear in its weakness; however, to the extent that the sign is posited as insignificant $=0$, original matter, the hidden foundation of any nature, can also present itself. If nature properly presents itself in its weakest talent, then the sign is, nature presenting itself in its most powerful talent, $=0 . "$ Friedrich Hölderlin, "The Significance of Tragedies," in Essays and Letters on Theory, 89. 


\section{THE DIVINE FAITHLESSNESS OF HÖLDERLIN}

of each part and the unity of the whole as such which is the supreme separable, or the arche-partition." 25

It is also in this light that the line from the significance of tragedy concerning justice and law could be explained. Justice is not the domain of the sovereign Subject, neither is law the actualization of the sovereign Other in the calculable world. Judgement is the operation through which the original unity of intellectual intuition constantly makes itself manifest as the arche-separation, differentiating and individuating itself in the parts such that the unity is recognised in the part only as separation or partition. The part in their difference actualises the potential unity of all but only as separability, differentiation. Intellectual intuition comes here as that original difference or arche-separation which eternally differentiates and individuates. As Hölderlin writes, "Judgement, in the highest and strictest sense, is the original separation of object and subject which are most deeply united in intellectual intuition, that separation through which one object and subject become possible, the arche-separation." 26

The possibility of tragedy arises when this principle of individuation has to be expressed such that intellectual intuition becomes tangible. To hear the clamour of Being in its univocity which can only come to us as difference, as partition so that it no longer remains hidden, unknown and silent. How to unfold the world in its totality but only through its folding back, in the double folding back of man and god, their turning away from each other, which is also the sign of their unity? When Hölderlin writes that "the unity present in the intellectual intuition manifests itself as a sensuous one precisely to the extent that it transcends itself, that the separation of its parts occurs which too, separate only because they feel unified" 27 we need to understand this transcendence as a transcendence to nowhere but itself. A transcendence which is a "divine faithlessness" of man and god separating from each other such that one transcends to nothing but an arche-separation which is the condition of possibility of its individuation. By the same logic the whole is a living whole, a sensuous whole which is "determined and rich in content, on account of the liveliness of the parts, of their intensity." ${ }^{28}$ In becoming the whole, the part gains inwardness or intensity while the whole gains "life,"

25 Arche-separation or Urtheilung is seen by Hölderlin as the original separation through which subject and object are made possible which are unified in intellectual separation. Therefore arche-separation is pre-supposed by a whole which is its condition of possibility while in itself such separation is the judgement rendered on the ground of all beings. Therefore, Being exists in a state of arche-seperation which is to say in a state of alienation as a result of the Judgement rendered onto it. See Courtine, "Of tragic metaphor," 61-64. See also, Hölderlin, "Judgment and Being," 37-38.

${ }^{26}$ Hölderlin, "Judgment and Being," 37.

${ }^{27}$ Hölderlin, "On the Difference of Poetic Modes," 85.

${ }^{28}$ Ibid., 85.

(c) 2019 Soumick De

https://www.kritike.org/journal/issue 24/de june2019.pdf

ISSN 1908-7330

(cc) BY-NC-ND 
the being of the sensible. This is not a dialectical thinking of the part and whole, of man and God, where the whole (God) always comes before the part (man), because it is to the whole that the part has to sacrifice itself, negating and preserving itself in the whole. On the contrary, Hölderlin writes in his remarks on Oedipus "... god and man expressing themselves in the allforgetting form of infidelity - for divine infidelity is best to retain - so that the course of the world will not show any rupture and the memory of the heavenly ones will not expire." ${ }^{29}$ It is this separation where the gods have fled, where they are no longer with us such that all we can have is the displacement of our being in relation to god, the foreignness or nomadicity of our lives, wandering under the unthinkable, in all forgetfulness and divine faithlessness which is paradoxically also the arrival of the Gods among us but masked, in weakness. But again, this is also the proper way of their appearance. It is this resonance of the idea of dues absconditas ${ }^{30}$, who comes clothed and masked, hidden under the humble garb of a servant, the "original strength" presenting itself in its "weakest talent," $(S=0)$

In a fragment, Hölderlin writes:

Always yet marvellously for the love of men

God clothes himself

And hides his face from all knowing. ${ }^{31}$

What we find here is not only the problem of tragedy as a metaphor where god and man encounter each other, such that the divine is revealed but only through the destruction of the sign, which is made insignificant, meaningless so that the truth of the primordial unity can appear in the senselessness of the sign. As we pointed above it is this senselessness of the sign which (de)monstrates the language of tragedy to itself. It is also a mode of thinking which participate in the problem of theatre. A problem of masking and unmasking where one experiences the inner emptiness of all masks and seeks to complete it by filling it with all the difference between the finite and infinite, between man and god. The structure of the metaphor as the vessel for tragedy has to see thus not from the perspective of an approximation of meaning but truly as a transport, a passage for god to appear but as no-one. We hear an echo-an echo before the voice-of Kierkegaard's knight of faith

${ }^{29}$ Friedrich Hölderlin, "Remarks on Oedipus," in Essays and Letters on Theory, 108.

${ }^{30}$ On the problem of deus absconditas and its relevance in Hölderlin and also the difference of interpretation between Jean Francois Courtine and Philippe Lacoue-Labarthe regarding the point see Courtine, "Of tragic metaphor," 71 and Phillipe Lacoue-Labarthe, "Hölderlin's theatre," trans. by Simon Sparks, in Philosophy and Tragedy, 129.

${ }^{31}$ Friedrich Hölderlin, Sämtliche Werke (Größe Stuttgarter Aufgabe), Vol. II, ed. by Friedrich Beißner (Stuttgart: Kohlhammer, 1985), 256. As quoted in Courtine, “Of tragic metaphor," 71.

(c) 2019 Soumick De

https://www.kritike.org/journal/issue 24/de june2019.pdf

ISSN 1908-7330 


\section{THE DIVINE FAITHLESSNESS OF HÖLDERLIN}

who appears as a bourgeois in his Sunday best because he only plays the role of the knight of faith. It is only as play, where the being of the actor resembles the being of no-one that god shows himself but as nothing which is again not to say as negation but the sensuous experience of an originary separation. The language of tragedy as "monstration," as expressing the desire for an alien god who is absconding, is, for Hölderlin, the problem of theatre per excellence because the failure of meaning is the very success of the truth of tragedy as arche-separation.

But if the metaphor as transport captures the true theatricality of tragic thinking then it also corresponds to the idea of translation. To understand the problem of translation as not merely a literary act but a veritable theatre of the future, a modern theatre which anticipates the failure of modern theatre as theatre of (de)monstration, a place of congregation in the classical sense of the word. A translation-theatre, like Mallarme would later imagine a book theatre (Mallarme who was deeply influenced by Hölderlin) which not only asserts the disappearance of a communal sacred place as the locus of theatre to take place but the imagination of a new inhabitation for theatre which is that of language. To re-imagine Julia Kristeva's famous title "Modern Theatre Does Not Take (a) Place," 32 it takes place within language. But this language is not of representation but that of repetition, a language of translation, even a "foreign," improper, monstrous and alien language.

When Walter Benjamin wrote "The Task of the Translator," 33 it is evident that he had Hölderlin's translations in mind which is proved by the last section of the piece which is devoted almost exclusively to Hölderlin's translations of the Greek tragedies. ${ }^{34}$ Irrespective of this relation and the almost impenetrable complexity of Benjamin's own language, a certain similarity of the idea of translation as explained by Benjamin with an idea of theatre seems to emerge here in context of Hölderlin's own translation. Benjamin argues that translation is never about the transmission of subject matter because all that one can transmit are facts of communication and never

32 Julia Kristeva's essay talks of the modern predicament of theatre which has overcome its earlier dialectical logic of theatrical separation and topological distribution. See Julia Kristeva, "Modern Theater Does Not Take (a) Place" trans. by Alice Jardine and Thomas Gora in Mimesis, Masochism, \& Mime: The Poltics of Theatricality in Contemporary French Thought, ed. by Timothy Murray (Ann Arbor: The University of Michigan Press, 1997).

33 See Walter Benjamin, "The Task of the Translator," in Illuminations: Essays and Reflections, trans. by Harry Zohn, ed. by Hannah Arendt (New York: Schocken Books, 1968).

34 After his efforts to write the tragedy "The Death of Empedocles" Hölderlin embarked upon translating the tragedies of Sophocles particularly "Oedipus" and "Antigone." The translation project was governed by the same tragic fascination with the Greeks which was the source of Hölderlin's poetic genius. The translations were finally published in 1804 by Friedrich Wilmans.

(C) 2019 Soumick De

https://www.kritike.org/journal/issue 24/de june2019.pdf

ISSN 1908-7330

(c) ) BY-NC-ND 
"truth" of the original work of art. However it is through translation that great works continue to survive in their greatness because a true work would always offer itself up to translation, which is the force or potential of its translatability, the "afterlife" of the work which like a cloud always surrounds the "life" of the text but also gives it to history so that the philosopher can comprehend the natural life of the work though its (after)life in history only through translation. Hence it is through translation that the work gathers its fame. Moreover, it is through translation that the kinship of languages is maintained. What Benjamin means by a kinship of two languages is not the resemblance of words or similar works of literature but something which seems to be clearly inspired by Hölderlin's idea of uni-totality. Benjamin writes

All suprahistorical kinship between languages consists in this: in every one of them as a whole, one and the same thing is meant. Yet this one thing is achievable not by any single language but only by the totality of their intentions supplementing one another: the pure language. ${ }^{35}$

The intention (intentio) of translation is thus meant not as a reproduction or representation but as a supplement which needs to be read here as a repetition in the target language not of the original text but the difference which separates the two. Hence to be faithful to the original, in this schema of thought, would be to display a certain infidelity such that what makes appearance in the target language is not the original text, which is impossible but its translatability. While from the point of view of the translated text what appears is the impossibility of translation or its untranslatability. In other words, it is through translation that translatability un-translates or remains eternally unfulfilled. We will not go further into the details of Benjamin's text. Suffice it to say here that it is this idea of translation, that Benjamin found Hölderlin to a be a master of, which becomes evident when we read what Benjamin says of Hölderlin's translations that they evoke the danger inherent to all translations where "the gates of language thus expanded and modified may slam shut and enclose the translator with silence." 36 Now this idea of the translatability of the work which instead of being fulfilled and exhausted remains incomplete in the act of translation thus producing the inexhaustible possibility of further translation remarkably corresponds to the idea of

${ }^{35}$ Benjamin, "The Task of the Translator," 74.

${ }^{36}$ Ibid., 81. 
theatre - here we follow Badiou but only minimally ${ }^{37}$ - where the theatrical text exists as a not-all, which is to say something which does not belong to itself but only finds its completion in the act of enactment. The text has no purpose outside its enactment. Hence it remains as a virtuality, as something translatable which can only be completed by its translation into performance. But every performance instead of completing or fulfilling the theatricality of the text enhances it, instead of exhausting its possibility paradoxically increases it opening it up to further possibilities of performance, of more enactments of its theatricality, of more interpretations and translations. This is the mysterious double binding of the taking place of theatre which both completes and incompletes the theatrical text. Hence a single text is reenacted throughout history whose afterlife only contributes to the greatness of its original life. In this sense we would argue that Hölderlin's translations are not merely theatrical, but it is the taking place of a modern theatre, a theatre of translations while at the same time his understanding of the tragic metaphor opens up within philosophy something akin to a theatre of repetitions.

\section{The General Problem as a Problem of Language: Madness}

But one would be still justified in arguing that is it not the German language in which all this takes place? How could this German language be hollowed out of its mastery? How can it be stripped of its aristocracy, the aristocracy of the masters like Goethe and Schiller who were re-turning to the Greek masters in an attempt to find a legitimacy of their own supremacy? If it is true that it is in the Germany of the early nineteenth century that a genuinely historical dimension of the west crystallised itself then what role did the language of Hölderlin play in it? Is it one of aristocracy which borrows

37 Alain Badiou goes on to elaborate on this thesis by constructing four elemental dimensions of the theatre-truth namely its a) evental dimension inscribed in the relation between the theatrical text and its performance, b) its experimental dimension inscribed in its treatment of time, producing an artificial time where the instant encounters eternity, c) its quasi-political dimension which is produced through the universality of the idea by being an art form which is quintessentially public in nature. d) And finally, the amplifying dimension of the theatrical truth which elaborates its relation with history presenting it in a fashion which is neither representational nor absolutely aesthetic devoid of politics. It is the moment where a real historical sequence would meet the artificiality of time making that sequence immortal. We have tried to read the philosophy of Augustine in order to find a movement within that philosophy which we can call theatrical from all this perspective adhering to Badiou's schematization in spirit and not strictly by letter. See Alain Badiou, Rhapsody for the theatre (London and New York: Verso, 2013), 101-103.

${ }^{37}$ For a detailed analysis of this problem see Jean Laplanche, Hölderlin and the Question of the Father, ed. and trans. by Luke Carson (Victoria, Canada: ELS Editions, University of Victoria, 1992).

(c) 2019 Soumick De

https://www.kritike.org/journal/issue 24/de june2019.pdf

ISSN 1908-7330

(c) BY-NC-ND 
its cultural debt from the Greeks? Or is it a language whose sovereignty is challenged by the work of the poet which constantly moves into that which is not a work, which is an absence of work, in other words madness. Is it a language which seeks its condition of possibility from the very loss of language, a single language which can continuously speak of the poem and madness? What is the relation between the two that Hölderlin's work is a testimony to? Is it the silence of an anonymity which is to say the silence of that which is distant from a work that speaks; is it this distance which is brought into the proximity of language in Hölderlin? The flight of the gods that throws men into the mortal domain of the world, into the domain of history is also the imminence of the Gods. But how can a language speak the silence of anonymity when it has to say something ... always something? It is here perhaps that the relation of language and madness is born.

In an essay titled "The Father's 'No'" 38 which first appeared in Critique in 1962 as a review of Jean Laplanche's book Hölderlin and the Question of the Father, Michel Foucault poses this as the general problem of language and history in the modern times. How can a single language speak the language of the poem and the language of madness? Not the sovereign language which can identify what is a poem and what is madness but to understand language topologically, as a space in which one can continuously move from madness to literature and back in infinite speed.

He argues that the transition from the middle ages to renaissance, saw a new modality of the hero figure in the form of the artist whose work and whose life would not only mirror each other, but the work would be taken as an exploit, as the very determining factor of the life of the artist through which the "ephemeral actions" of his life finds its eternal truth, while the life of the artist is seen as the "natural birthplace" of this truth. The truth of the artistic genius, the discovery and recognition of that genius, which Giorgio Vasari's vite-The lives of Artists (1991)-commemorated, would always be preceded by the existence of that truth, prior to all recognition, before all discoveries. The recognition would merely be a twist in the narrative of the genius life, fraught with a series of vicissitudes. For example, Giotto was a shepherd sketching sheep when Cimabue discovered him on a rock. An apprenticeship follows, where the master becomes the disciple and the disciple is recognised as the true hero of the narrative. The work that he then produces becomes a testimony to this truth of his existence, the truth of his genius. It is this heroic mode of epic perception which became the method of approaching the truth of the artist and his work. However, as Foucault shows this unity was always precarious, threatened by that which was not

${ }^{38}$ Michel Foucault, "The Father's 'No'," in Language, Counter-Memory, Practice: Selected Essays and Interviews, ed. by Donald Bouchard, trans. by Donlad Bouchard and Sherry Simon (Ithaca, NY: Cornell University Press, 1977), 68-86.

(c) 2019 Soumick De

https://www.kritike.org/journal/issue 24/de june2019.pdf

ISSN 1908-7330 
work but which nonetheless was inalienable from the heroic narrative of the artist genius. The "distraught hero" who is consumed by his passion, the "alienated hero," lost in his work, who becomes alienated not only from the world but tragically from his work, or the "misunderstood hero" who is not recognised in his lifetime. Through such episodes that which is not the work is interwoven into the unity of the artist and his work. However, with the passing of the heroic dimension, madness becomes the very threshold along which the unity of the artist and his work and that which is not works, which is the absence of work came to be determined. But strangely it is this heroic unity of the artist and his work, which gets re-enforced though negatively through the developing discourses of madness. It is madness which identifies the artist to his work as separate from everyone, but it is also madness which situates the artist not just inside his work but outside as well when it "blinds him to the things he sees and makes him deaf to even his own words." ${ }^{39}$ It is this psychology of the artist, even before a discourse of clinical pathology is born, that Foucault identifies as the discursive tendency of understanding the artist and his work. It is done by negating the external relation or unity of the artist and his work and introducing a more subterranean path, a path leading to all that is not reflected in the work, to all that is not external to the unity of the artist and the work but the interior relation between what is work and what is the absence of work. With the loss of divine sovereignty, language becomes the great sovereign which emulates the sovereign prerogative of deciding upon the exception, in this case that which is work and that which is an exception to work.

What is original to Foucault's analysis is to recognise that in the psychological negation of the unity of the artist and his work there is a more sinister affirmation of the same unity which would enable the artist to be the guarantor of truth which is sought through his work. In other words, the relationship between art and madness, the discourse (psychological) which identifies what is a work and what is not in relation to the successive events of the artists life silently repeats the sovereignty of the artistic subject which the heroic discourse of the genius represented during renaissance. What Hölderlin exposes is a threshold of this relation between madness and art by dissolving this unity and posing the problem of the relation exclusively at the level of language. The repetitions of the lack of the Father figure which comes over and over in Hölderlin's imagination which informs both his life and work - for example it has been argued by scholars like Jean Laplanche of the presence of Schiller as a replacement of the father figure which is nevertheless abandoned. ${ }^{40}$ This proximity with Schiller which is later realised in the

${ }^{39}$ Ibid., 75.

(c) 2019 Soumick De

https://www.kritike.org/journal/issue 24/de june2019.pdf

ISSN 1908-7330

(c) BY-NC-ND 
distance which Hölderlin creates between himself and the master can be seen in the tragic light of the unfaithful presence of the gods in their absence. However, in Hölderlin the problem of distance and proximity is always played out in the space of language. Language starts functioning as the mirror which approximates life only to recognise the distance hidden in the proximity. The work becomes a "measure" of what it is not, of the absence of the real. But even this dual relationship of the mirror which can avert madness by the joy of artistic expression, by creating a double in the world of language of the impossible force of the original lack, an emptiness which designates the absence of all work is not enough for Hölderlin. What Hölderlin seeks to expose is the very limit of language in language itself. It is a limit which constitutes a work on the very threshold of its absence. The flight of the immortals pushes existence to its inaccessible limit where nonetheless mortality is touched by the divine. The anguished endurance of the hero, in absence of his exploits characterises the discontinuity between the artist and his work. It is this original distance between the artist and his work which plays out the arche-separation of tragedy in the very enactment of artistic creation. But at the same time, it is this discontinuity which marks the language of Hölderlin with a certain ellipsis which traces the limit of language itself, where it no longer functions through communication of meaningful words. This is not difficult language in terms of the complexity of significance which nonetheless produces meanings which can be deciphered. It is not a codification of language for the sake of hidden knowledge. Nor is it the complex use of images and metaphors which distorts language. In other words, language does not become rhetorical because it seeks to convince. Here language operates as a forcing of that which it is not, the work forces the threshold or the gap which differentiates the work from its absence into the work itself. The work as a unity between the desire of the artistic subject and the object of its satisfaction therefore becomes something akin to what Hölderlin valued so much in tragedy-intellectual intuition. However, it is only a displaced unity because the work expresses this unity only by evoking its absence. It is this arche-separation or the foundational lack which makes the modern work of art, for Hölderlin not merely tragic in its content, but in its form. Modern artistic creativity is tragic creativity because it takes art to the limits of signification such that artistic form exposes itself to its other-life. However, artistic form cannot appropriate life intrinsically. For Hölderlin, form rather than being separated from life as an objective external reality, exposes in its emptiness the negativity of its relation to life. The absence of signification becomes the condition of possibility for the symbolic to exist. The threshold of tragic language carries the trace of this foundational lack or absence.

(c) 2019 Soumick De

https://www.kritike.org/journal/issue 24/de june2019.pdf

ISSN 1908-7330

(cc) BY-NC-ND 
Thus, it is like the father's "no" which never forecloses the presence. The father's absence, as Foucault, following Lacan explains, is never the absence of the real individual who bears the name of father which produces symbolic distortions into images and forms. It is rather the father, as the signifier who instead of naming himself, of nominating himself in the role of the father according to the Law, leaves the place of signification empty. The effect of a lack of nomination, the absence of the limit that the signifier Father is supposed to set up in the psychic field, the loss of its meaning forces the upsurge of the phantasms of psychosis.

Hence, following Foucault we would argue that two moments are to be detected in Hölderlin. The initial tragic moment of the reciprocal withdrawal of the gods to their ether and the hero to his terrestrial world is reflected in the historical consciousness of the poet by the effacement of Greece and the arrival of the Hesperian reality. Interestingly, to be witness to this withdrawal is the tragic poetic gesture per excellence for Hölderlin. We find it echoed best in his "Bread and Wine" when he writes

But, my friend, we have come too late. Though the gods are living, Over our heads they live, up in a different world. Endlessly there they act and, such is their kind wish to spare us, Little they seem to care whether we live or do not. ${ }^{41}$

And a second but simultaneous "zone" is created where language approaching its limit, loses itself by being absolutely unfamiliar to itself. Wandering under the impossible, here language is conditioned by that which comes from elsewhere. Perhaps the most unambiguous example of this threshold of language, when language confronts its own abyss, comes in Hölderlin's translation of Antigone. Georg Steiner notes about this translation that "The opening word of Antigona is a willed monster: Gemeinsamschwesterliches!" 42 It is this "monstrous" translation which brings out a naked literalness of language in Antigone describing the royal sisters together in the beginning of the play which is immediately repeated when Antigone calls out to Ismene's "head": "O Ismenes haupt!" 43 Steiner notes "such carnal immediacy is appropriate to one who has, just before dawn, confronted, given swift and spontaneous sacrament to, the body of her

\footnotetext{
${ }^{41}$ Hölderlin, "Brod und Wein / Bread and Wine," 185.

42 (Steiner 1996: 85)

George Steiner, Antigones: How the Antigone Legend Has Endured in Western Literature, Art, and Thought (New Haven and London: Yale University Press, 1996), 85.

${ }^{43}$ Ibid.
}

(c) 2019 Soumick De

https://www.kritike.org/journal/issue 24/de june2019.pdf

ISSN 1908-7330

(c) BY-NC-ND 
brother." ${ }^{44}$ But it is not merely the context of the dramatic situation which warrants the use of such physical and primitive ${ }^{45}$ language. The primordial words dissolve into the discordance of an impossible language; a barren and ancient language which is not only deprived of rational meaning but hollowed out of any form of signification. And yet it is language which is exposed to its own monstrous other, its alien essence which permanently escapes itself such that all we are left with is language as the measure of an immeasurable gap: a tragic arche-separation is forced into existence as the psychotic phantasm of language. The tragic dissonance of the poem finds a vanishing point within the delirious materiality of the absence of work.

Foucault writes, "the trajectory that outlines the flight of the gods and that traces, in reverse, the return of men to their native land is indistinguishable from this cruel line that leads Hölderlin to the absence of the father, that directs his language to the fundamental gap in the signifier, that transforms his lyricism into delirium, his work into the absence of a work." 46 It is here that the sovereignty of the artistic subject, which reflects the sovereignty of language collapses giving rise to the "enigma of the similarity" that the work shares with the absence of work, which the poetic utterances share with the delirious whispers of the mad. In pushing a work towards its own dissolution, Hölderlin succeeded in not only dissolving the heroic unity of the artist and his work, but in creating an order of language which could be common to both the poem and madness. This language is not the sovereign language which identifies itself as the sovereign who can decide on what a work is and what is not. This language always arrives from elsewhere, a there which is always a here, a silence which is always heard while speech dissolves into madness.

Department of Theatre and Performance Studies, School of Arts and Sciences Jawaharlal Nehru University, India

\section{References}

Badiou, Alain, Rhapsody for the theatre (London and New York: Verso, 2013). Benjamin, Walter, "On Language as Such and on the Language of Man," trans. by Edmund Jephcott in Selected Writings: Volume 1, 1913-1926, ed. by Marcus Bullock and Michael W. Jennings (Cambridge, MA: The Belknap Press of Harvard University Press, 1996).

\footnotetext{
44 Ibid., $85-86$.

${ }^{45}$ See ibid., 85.

${ }^{46}$ Foucault, "The Father's 'No',"84.
} 


\section{2}

\section{THE DIVINE FAITHLESSNESS OF HÖLDERLIN}

"The Task of the Translator," in Illuminations: Essays and Reflections, trans. by Harry Zohn, ed. by Hannah Arendt (New York: Schocken Books, 1968).

Courtine, Jean-François, "Of tragic metaphor," in Philosophy and Tragedy, ed. by Miguel de Beistegui and Simon Sparks (London and New York: Routledge, 2000).

Foucault, Michel, "The Father's 'No'," in Language, Counter-Memory, Practice: Selected Essays and Interviews, ed. by Donald Bouchard, trans. by Donlad Bouchard and Sherry Simon (Ithaca, NY: Cornell University Press, 1977).

Hölderlin, Friedrich, "Brod und Wein / Bread and Wine," trans. by M. Hamburger, in Hyperion and Selected Poems, ed. by Eric Santner (New York: Continuum, 1990).

"Judgment and Being," in Essays and Letters on Theory, trans. and ed. by Thomas Pfau (Albany, NY: SUNY Press). "On the Difference of Poetic Modes," in Essays and Letters on Theory, trans. and ed. by Thomas Pfau (Albany, NY: SUNY Press). "Remarks on 'Antigone'," in Essays and Letters on Theory, trans. and ed. by Thomas Pfau (Albany, NY: SUNY Press).

"Remarks on Oedipus," in Essays and Letters on Theory, trans. and ed. by Thomas Pfau (Albany, NY: SUNY Press). Sämtliche Werke (Größe Stuttgarter Aufgabe), Vol. II, ed. by Friedrich Beißner (Stuttgart: Kohlhammer, 1985). "Selected Letters: No. 236, To Casimir Ulrich Böhlendorff," in Friedrich Hölderlin: Essays and Letters on Theory, trans. and ed. by Thomas Pfau (Albany, NY: SUNY Press). The Death of Empedocles: A Mourning-Play, trans. by David Farrell Krell (Albany, NY: SUNY Press, 2008).

"The Perspective from which We Have to Look at Antiquity," in Essays and Letters on Theory, trans. and ed. by Thomas Pfau (Albany, NY: SUNY Press).

"The Significance of Tragedies," in Essays and Letters on Theory, trans. and ed. by Thomas Pfau (Albany, NY: SUNY Press). Werke und Briefe, ed. by Friedrich Beissner (Frankfurt: Insel Verlag, 1969).

Kristeva, Julia, "Modern Theater Does Not Take (a) Place" trans. by Alice Jardine and Thomas Gora in Mimesis, Masochism, E Mime: The Poltics of Theatricality in Contemporary French Thought, ed. by Timothy Murray (Ann Arbor: The University of Michigan Press, 1997).

Lacoue-Labarthe, Phillipe, "Hölderlin and the Greeks," in Typography (Stanford, CA: Stanford University Press, 1998).

(c) 2019 Soumick De

https://www.kritike.org/journal/issue 24/de june2019.pdf ISSN 1908-7330

(c) BY-NC-ND 
"Hölderlin's theatre," trans. by Simon Sparks, in Philosophy and Tragedy, ed. by Miguel de Beistegui and Simon Sparks (London and New York: Routledge, 2000).

Laplanche, Jean, Hölderlin and the Question of the Father, ed. and trans. by Luke Carson (Victoria, Canada: ELS Editions, University of Victoria, 1992).

Schiller, Friedrich, "Naïve and Sentimental Poetry," in Naïve and Sentimental Poetry and On the Sublime: Two Essays, trans. by Julius A. Elias (New York: Frederick Ungar Publishing Co., 1966).

Steiner, George, Antigones: How the Antigone Legend Has Endured in Western Literature, Art, and Thought (New Haven and London: Yale University Press, 1996)

Winckelmann, Johann Joachim, "Thoughts on the Imitation of Greek Works in Painting and the Art of Sculpture," in Johann Joachim Winckelmann on Art, Architecture, and Archaeology, trans. by David Carter (Rochester and New York: Camden House, 2013). 